\title{
Effects of Pyrroloquinoline Quinone and Vitamin C on Diabetes Associated Testicular Dysfunction and Oxidative Damages in Testis of Streptozotocin-Induced Diabetic Mice: Histopathological Study
}

\author{
Narendra Kumar* and Anand Kar \\ School of life Sciences, Devi Ahilya University, Takshashila Campus, Indore, India
}

\begin{abstract}
Received: October 02, 2017; Accepted: November 03, 2017; Published: November 10, 2017
*Corresponding author: Narendra Kumar, School of Life Sciences, Devi Ahilya University, Takshashila Campus, Indore, Madhya Pradesh, India, Tel: +91 9425481242; Fax+91 731 2360026; E-mail: narendrakumar93@gmail.com
\end{abstract}

\begin{abstract}
The aim of this study was to investigate the hitherto unknown potential of Pyrroloquinoline Quinone (PQQ) in regulating diabetes associated testicular dysfunctions and oxidative damages in testis of adult mice. Seven groups such as normoglycemic and PQQ treated controls; STZ-treated and STZ + PQQ treated $(5,10$ and $20 \mathrm{mg} /$ $\mathrm{kg} /$ day, separately) and STZ + Vit.C (50 mg/kg) were established. After 18 days of experimentation, alterations in the markers of oxidative stress, various antioxidants, lipid profile, serum insulin, testosterone and testicular histology were evaluated. Administration of single dose of STZ (150 mg/kg b.wt) enhanced not only testicular lipid peroxidation and lipid hydroperoxides levels; but also serum concentration of glucose, cholesterol, triglyceride, low density lipid and very low density lipid; with a parallel decrease in serum insulin, testosterone, and different antioxidants in diabetic mice. However, on simultaneous administration of PQQ particularly at a dose of 20 $\mathrm{mg} / \mathrm{kg}$, most of these adverse effects were ameliorated. While the PQQ $(20 \mathrm{mg} / \mathrm{kg})$ decreased the serum glucose by $50 \%$, it increased insulin and testosterone levels by $59 \%$ and $169 \%$ respectively in STZinduced animals, these results suggest that PQQ may have potential to ameliorates diabetes-induced testicular dysfunction.
\end{abstract}

Keywords: Diabetes mellitus; PQQ; Insulin; Testosterone; Oxidative stress; Testis; Vitamin C

\section{Introduction}

Diabetes mellitus (DM) is primarily a metabolic disorder and is characterized by hyperglycemia [1]. Diabetic condition increases oxidative stress that is believed to be the result of increased production of reactive oxygen species (ROS) and decreased antioxidant defense system [2]. In fact, tissue injury due to free radical damage acts as an important factor in the pathogenesis and complication of DM. It is also believed that an increase in ROS production causes non-specific modifications in nucleic acids, protein and phospholipid structures that leads to damage in deoxyribonucleic acid (DNA) and ribonucleic acid (RNA) as well as changes in the levels of antioxidant enzymes [3].

Diabetes is also known to exert negative effects on male fertility through hyperglycemia-induced testicular dysfunctions leading to atrophy of sex organs; decrease in testosterone level; loss in libido and in sperm count and motility [4, 5]. Agbaje, et al. [6] also reported that streptozotocin (STZ)-induced diabetic animals show a significant increase in the level of fragmented DNA in sperms. These adverse effects are thought to be due to DM associated oxidative stress [7-9]. These observations led us to assume that a potent antioxidant is crucial in reducing the damage caused by oxidative stress. Some experimental, epidemiological and clinical studies also emphasize that antioxidants might be helpful for treating diabetes and its complication [10-14].

Pyrroloquinoline Quinone (PQQ) is a ubiquitous molecule that is reported to be beneficial for growth and stress tolerance in both bacteria and higher organisms $[15,16]$. In recent years, this has been found to act as an antioxidant [17-21]. Both in vivo and in vitro studies suggest that $\mathrm{PQQ}$ can protect against several types of oxidative damages and irradiation injury [22, 23]. Further, $\mathrm{PQQ}$ is found to be involved in regulating various physiological processes through its redox cycling property [16, 24-26]. In fact, PQQ is believed to possess potent antioxidant activity, much stronger than other quinones and enediols including ascorbic acid [27]. PQQ administration reverses the metabolic disorders and significantly improves lipid profile [28, 29]. Mechanistically, $\mathrm{PQQ}$ is involved in scavenging ROS, regulating calcium and insulin signaling pathways through PI3K/AKT cascade [30]. In fact, despite good amount of evidences on its antioxidative properties, so far nothing was investigated on its role in hyperglycemiainduced oxidative damages in testis of diabetic ones. Present one is an attempt in this direction.

\section{Materials and Methods}

\section{Chemicals}

STZ was procured from Sigma-Aldrich chemicals (St. Louis, MO, USA); Ellman's reagent, m-phosphoric acid, Thio-Barbituric Acid (TBA), sodium dodecyl sulphate, Tricarboxylic Acid (TCA) and Hydrogen Peroxide $\left(\mathrm{H}_{2} \mathrm{O}_{2}\right)$ were obtained from E. Merck Ltd., 
Mumbai, India. Assay kits for the estimation of different lipids, glucose, urea, and creatinine were procured from Transasia BioMedicals Itd., Solan, India. PQQ was purchased from Quality of Life Lab, USA. While testosterone kit (CLIA) was from Autobio Diagnostics Co., Ltd Zhengzhou, China; insulin estimation was done with ELISA kit from IRI Research Inc, lake view, Canada. All other chemicals were of reagent grade and obtained from Sisco Research Laboratories Pvt. Ltd., Mumbai, India.

\section{Animals}

Swiss albino male mice (7-8 weeks old), weighing $30 \pm 2 \mathrm{~g}$ were housed in polypropylene cages in a standard photoperiod (14 h light:10 $\mathrm{h}$ dark) and temperature $\left(27 \pm 1^{\circ} \mathrm{C}\right)$ controlled room with the provision of laboratory feed (Gold Mohur Feed, Hindustan Lever Limited, Mumbai, India) and water ad libitum. Animals were maintained in accordance with the guidelines of committee for the purpose of control and supervision of experiments on animals (CPCSEA), Ministry of Environment, Forest and Climate Change, New Delhi, Govt. of India. (Reg. No. 779/Po/Ere/S/03/CPCSEA)

\section{Induction of diabetes in mice}

Diabetes was induced in 24 hours fasted mice by a single intraperitoneal (i.p.) injection of STZ at $150 \mathrm{mg} / \mathrm{kg}$, dissolved in citrate buffer [31] ( $0.1 \mathrm{M}$ citrate, $\mathrm{pH} 4.5$ ) solution. After $72 \mathrm{~h}$ of STZ administration, the tail vein blood was collected to determine fasting blood glucose levels using a glucometer and mice with blood glucose more than $225 \mathrm{mg} / \mathrm{dl}$ were considered diabetic and included in the experiments.

\section{Experimental design}

Forty-nine healthy male mice were divided into seven groups of seven each. Group I animals receiving single (i.p.) injection of citrate buffer $(0.1 \mathrm{ml}, 0.1 \mathrm{M}$ citrate, $\mathrm{pH} 4.5)$ solution served as control. Group II, injected with single dose of citrate buffer and PQQ at $20 \mathrm{mg} / \mathrm{kg}$ for 15 days served as PQQ control; whereas those of group III, IV, V, VI and VII received single dose of STZ (150 mg/kg, i.p.). After rendering DM / hyperglycemia, animals of group IV, V and VI were treated (i.p.) with three different doses $(5,10$ and $20 \mathrm{mg} / \mathrm{kg} /$ day, respectively) of PQQ [32,33] and group VII received vitamin C (50 mg/kg, i.p.) for 15 days [16]. The dose concentrations were selected from previous studies [32, 33]. Total time duration of experimentation was 18 days $\left(1^{\text {st }} 3\right.$ days/ 72 hours for rendering diabetes/ hyperglycemia and 4th to 18th day for PQQ and Vit.C treatments).

\section{Preparation of serum and testis homogenate}

Mice were sacrificed by a mild ether anesthesia and blood from each animal was collected. Blood samples were centrifuged at $3000 \mathrm{rpm}$ for $5 \mathrm{~min}$; serum was separated and stored at $-20^{\circ} \mathrm{C}$ until estimation of different biochemical parameters including serum concentrations of insulin, testosterone, glucose, total cholesterol, and triglyceride, high density lipoprotein (HDL), low density lipoprotein (LDL) and very low density lipoprotein (VLDL). Testis homogenates were prepared in cold phosphate buffered saline (PBS, 0.1M, pH 7.4) using a homogenizer, which were then centrifuged at $15,000 \mathrm{~g}$ for $30 \mathrm{~min}$ at $4^{\circ} \mathrm{C}$ and the supernatant was used for the estimation of lipid peroxidation (LPO), super-oxide dismutase (SOD), catalase (CAT) and glutathione peroxidase (GPx) activities as well as reduced glutathione (GSH) content and lipid hydroperoxide ( $\mathrm{LOOH}$ ).

\section{Histopathological study of testis}

Immediately after exsanguinations, testis was washed with ice chilled phosphate buffer $(0.1 \mathrm{M}, \mathrm{pH} 7.4)$ and fixed in $10 \%$ formaldehyde for 24 hours. The tissues were dehydrated in the descending grades of isopropanol, finally cleared in xylene, and then embedded in molten paraffin wax [34]. Sections were cut at $5 \mu \mathrm{m}$ thicknesses, stained with toluidine blue and scrutinized under Nikon microscope with digital camera system (Nikon ECLIPSE 50i).

\section{Hormone estimation}

The serum testosterone was measured through ARCHITECT system by using a human Chemiluminescent Micro-Particle Immunoassay (CMIA) kit (ABBOTT Max-Planck-Ring 2, Wiesbaden, Germany) and following manufacturer's instructions. Estimations of serum insulin were done by commercially available kit and protocol manufactured by IRI Research Inc. lake view, Canada. IRI insulin is a solid phase ELISA.

\section{Analytical Procedures}

After completion of treatment, animals were sacrificed by mild ether anesthesia and testis were removed quickly, washed in PBS and processed for different parameters such as LPO, LOOH, SOD, CAT, GPx activities, GSH content and protein as well as serum was separated and stored at $-20^{\circ} \mathrm{C}$ until estimations of different biochemical parameters including glucose, total cholesterol, HDL, LDL and VLDL concentrations [35-45].

\section{Statistical analysis}

Data are expressed as means \pm SEM $(n=7)$. For the statistical evaluation, analysis of variance (ANOVA), followed by post hoc Newman-Keul's Multiple Comparison Test using the trial version of Prism 5 software (GraphPad Software, Inc., La Jolla, CA, USA) and Microsoft Office 2003 for windows. A "P" value of 0.05 or less is considered to be significant.

\section{Results}

Alterations in the body weight (g) of different experimental groups have been depicted in table 1. After comparing the body weight of 1st day, 4th day (the day when PQQ administration was started) and that of last day in the respective group, body weight (b.wt.) of the control animals as well as in PQQ (20 mg/ $\mathrm{kg}$ ) treated normoglycemic animals showed a normal growth at the end of experiment, while there was a loss in body weight in all the STZ treated of animals on the 4th day, which is the possible indications of rendering diabetes as compared with the $1^{\text {st }}$ day body weight of respective group of animals. While after administration of PQQ $(5,10 \& 20 \mathrm{mg})$ and Vit. C $(50 \mathrm{mg} / \mathrm{kg}$ for 15 days) there was no further body weight loss observed in respective group of animals as compared with $4^{\text {th }}$ and $18^{\text {th }}$ days 
body weight, which confirmed that the PQQ and Vit.C treatment in STZ-treated animals had protective role in body weight loss (Table 1).

With respect to different biochemical analyses a significant increase in the level of serum glucose was found in STZ treated animals $(P<0.001)$ as compared to normal control animals. However, on administration of PQQ at a dose of 5, 10 and 20 $\mathrm{mg} / \mathrm{kg}$ to diabetic animals; a significant decrease in the serum glucose level was observed with last 2 doses $(P<0.05$ and $P<0.001$ respectively, as compared to that of STZ-induced diabetic mice). Decreased glucose level was maximum (50\%) by $20 \mathrm{mg} / \mathrm{kg}$ of PQQ, while administration of Vit.C at $50 \mathrm{mg} / \mathrm{kg}$ to STZ-treated mice also decreased its level significantly $(P<$ 0.001 ) with a percentage decrease of $41 \%$. However, following administration of $20 \mathrm{mg} / \mathrm{kg}$ PQQ to normoglycemic mice, there was no significant alteration in glucose level as compared to that of normal animals (Figure 1). On changes in serum insulin level, it was significantly decreased in the STZ-induced diabetic mice $(P$
$<0.001$ ) as compared to normal animals. While administration of $20 \mathrm{mg} / \mathrm{kg} \mathrm{PQQ}$, to normoglycemic mice, did not alter insulin level significantly, its administration at 5,10 and $20 \mathrm{mg} / \mathrm{kg}$ to diabetic animals enhanced the hormone level in dose dependent manner. In fact, the highest dose of PQQ $(20 \mathrm{mg} / \mathrm{kg})$ increased its level by $59 \%$; while administration of Vit.C $50 \mathrm{mg} / \mathrm{kg}$ did not increase insulin level significantly (Figure 2). Serum testosterone level was also significantly decreased in the STZ-induced diabetic mice $(P<0.001)$, while administration of PQQ at 10 and $20 \mathrm{mg} / \mathrm{kg}$ to STZ-treated mice, increased its level significantly $(P<0.05$ and $P$ $<0.001$ respectively; as compared to that of STZ-induced mice) showing a $169 \%$ increase in the highest dose. No significant alteration was observed when $20 \mathrm{mg} / \mathrm{kg}$ of PQQ was treated to normoglycemic animals. Interestingly, on administration of Vit.C $50 \mathrm{mg} / \mathrm{kg}$ in STZ-treated diabetic animals a significant increase $(P$ $<0.05$ ) in the testosterone level was observed with a percentage of $62 \%$ as compared to STZ-treated diabetic animals (Figure 3).

Testicular LPO was increased significantly $(P<0.001$ as

Table 1: Alterations in the body weight $(\mathrm{g})$ on $1^{\text {st }}, 4^{\text {th }}$, and on $18^{\text {th }}$ (last) day of experimentation in different experimental groups of animals

\begin{tabular}{|c|c|c|c|}
\hline & \multicolumn{3}{|c|}{ Alteration in body weight (g) } \\
\hline Groups & $\mathbf{1}^{\text {st }}$ Day & $\mathbf{4}^{\text {th }}$ Day & $\mathbf{1 8}^{\text {th }}$ Day \\
\hline Control & $29.00 \pm 1.632$ & $30.50 \pm 1.002$ & $35.00 \pm 1.154$ \\
\hline PQQ 20 mg & $29.65 \pm 1.754$ & $31.40 \pm 0.914$ & $35.95 \pm 1.250$ \\
\hline STZ & $28.35 \pm 1.463$ & $26.00 \pm 0.925$ & $22.00 \pm 1.290$ \\
\hline STZ + PQQ 5mg & $28.85 \pm 1.069$ & $26.00 \pm 1.121$ & $27.00 \pm 1.112$ \\
\hline STZ + PQQ 10mg & $29.00 \pm 1.290$ & $26.50 \pm 1.231$ & $27.51 \pm 0.975$ \\
\hline STZ + Vit.C & $29.50 \pm 0.816$ & $27.00 \pm 0.936$ & $26.50 \pm 0.487$ \\
\hline
\end{tabular}

Data are expressed in mean \pm SEM $(n=7)$

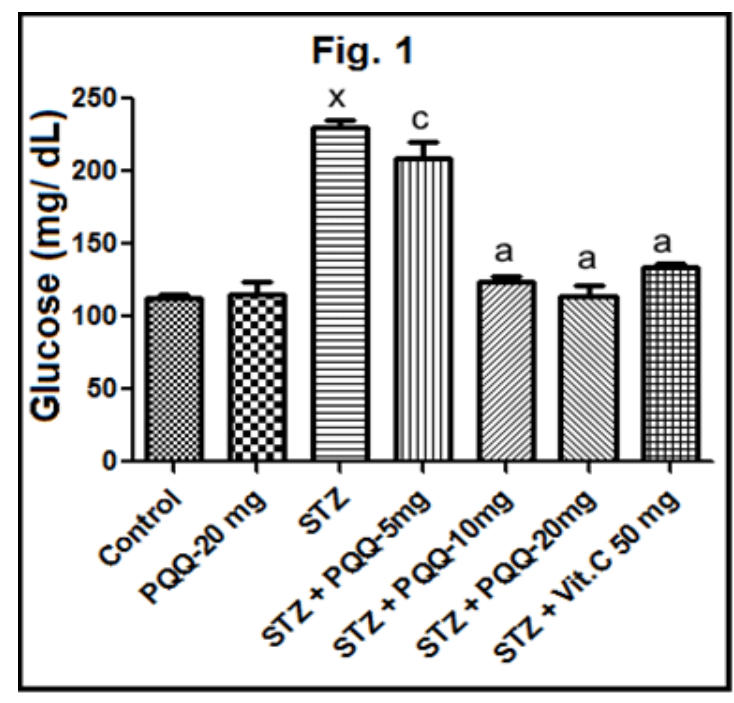

Figure 1: Effects of $P Q Q(5,10$ and $20 \mathrm{mg} / \mathrm{kg} / \mathrm{d}$, i.p. $)$ for 15 days, in serum glucose. Data are mean \pm S.E.M. $(\mathrm{n}=7)$. ${ }^{\mathrm{x}} P<0.001$ as compared to the respective control values. ${ }^{\text {a }} P<0.001$ and ${ }^{c}, P<0.05$ as compared to the respective STZ treated values. ${ }^{\text {STZ, }}$ Streptozotocin, PQQ, Pyrroloquin-

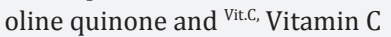

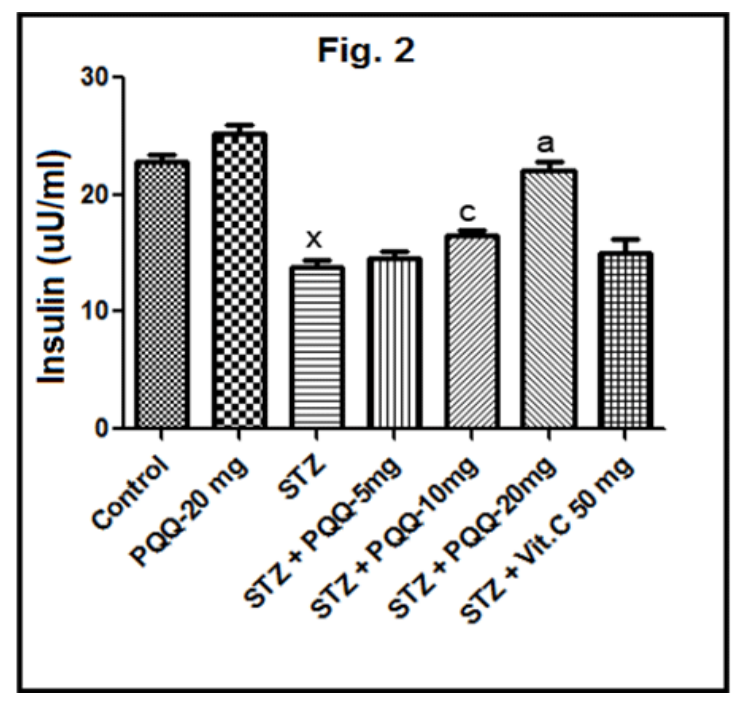

Figure 2: Effects of PQQ (5, 10 and $20 \mathrm{mg} / \mathrm{kg} / \mathrm{d}$, i.p.) for 15 days, in serum insulin $(\mu \mathrm{U} / \mathrm{ml})$ level. Data are mean \pm S.E.M. (n=7). ${ }^{x}, P<0.001$ as compared to the respective control values. ${ }^{a,} P<0.0001$ and ${ }^{c}, P<0.05$ as compared to the STZ treated value. ${ }^{\text {STZ }}$, Streptozotocin, ${ }^{\mathrm{PQQ}}$ Pyrroloquinoline quinone and ${ }^{\text {Vit.C, }}$ Vitamin C 


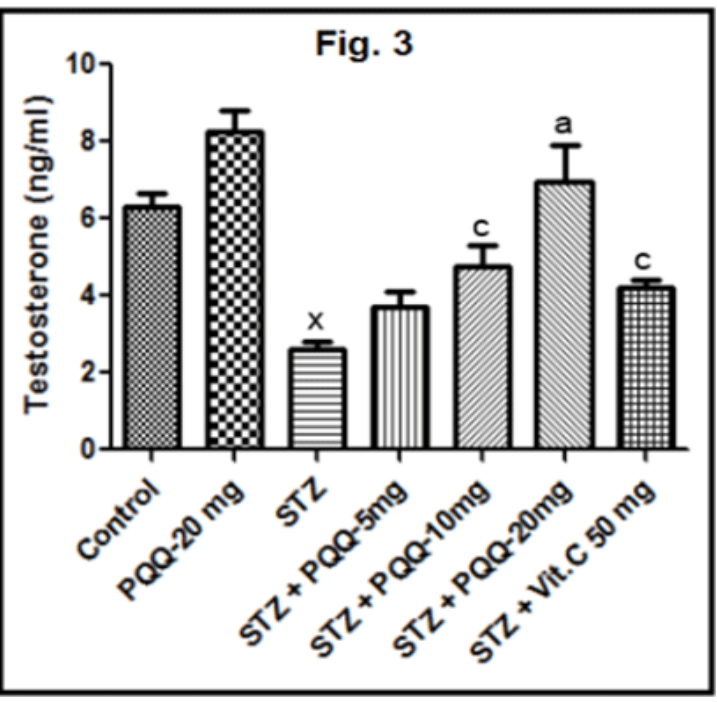

Figure 3: Effects of $\mathrm{PQQ}(5,10$ and $20 \mathrm{mg} / \mathrm{kg} / \mathrm{d}$, i.p.) for 15 days, in serum testosterone $(\mathrm{ng} / \mathrm{ml})$ level. Data are mean \pm S.E.M. $(\mathrm{n}=7) .{ }^{x} P$ $<0.001$ as compared to the respective control values. ${ }^{\text {a, }} P<0.001$ and

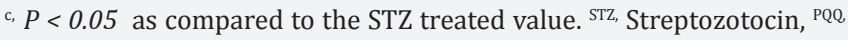
Pyrroloquinoline quinone and ${ }^{\text {vit.C. }}$ Vitamin C

compared to that of control ones) following the STZadministration. When PQQ (5, 10 and $20 \mathrm{mg} / \mathrm{kg})$ was administered to STZtreated mice, a significant decrease $(P<0.001$, for all $)$ in LPO level was observed as compared to that of STZ-induced diabetic mice. However, out of the three doses of PQQ, $20 \mathrm{mg} / \mathrm{kg}$ was again found to be most effective exhibiting the highest percentage decrease, i.e., 79\%. Administration of $20 \mathrm{mg} / \mathrm{kg} \mathrm{PQQ}$ to normoglycemic mice, did not significantly alter LPO level as compared to normal control ones, while administration of Vit.C at $50 \mathrm{mg} / \mathrm{kg}$ to STZtreated mice decreased the LPO level significantly $(P<0.001)$, with a percentage decrease $49 \%$ (Figure 4). Similarly with respect to testicular $\mathrm{LOOH}$ level, STZ administration increased its level significantly $(P<0.001$ as compared to that of control ones). When PQQ $(5,10$ and $20 \mathrm{mg} / \mathrm{kg}$ ) was administered to STZ-treated mice, a significant decrease $(P<0.001$, for all $)$ in $\mathrm{LOOH}$ level was observed in all the tested doses as compared to that of STZ-induced diabetic mice. However, out of the three doses of PQQ $20 \mathrm{mg} / \mathrm{kg}$ was found to be most effective, with a $59 \%$ decrease, while administration of Vit.C at $50 \mathrm{mg} / \mathrm{kg}$ to STZtreated mice decreased the LOOH level significantly $(P<0.001)$, with a percentage decrease $35 \%$ (Figure 5).

With respect to different antioxidants status of testis, STZ administration decreased the SOD activity significantly $(P<$ 0.05 as compared to that of control ones), after PQQ $(20 \mathrm{mg} / \mathrm{kg})$ administration in normoglycemic mice, no singificant alteration was observed. However, when three different test doses of PQQ were administered to STZ-treated mice, a marked increase in SOD level was observed only with 10 and $20 \mathrm{mg} / \mathrm{kg}$ of PQQ $(P<0.05$ and $P<0.001$ respectively, as compared to that of STZ-induced diabetic mice). Of course the higher dose increased SOD activity to a greater extent with a percentage increase of $91 \%$. However, A significant increase $(P<0.05)$ with a percentage of $47 \%$ was

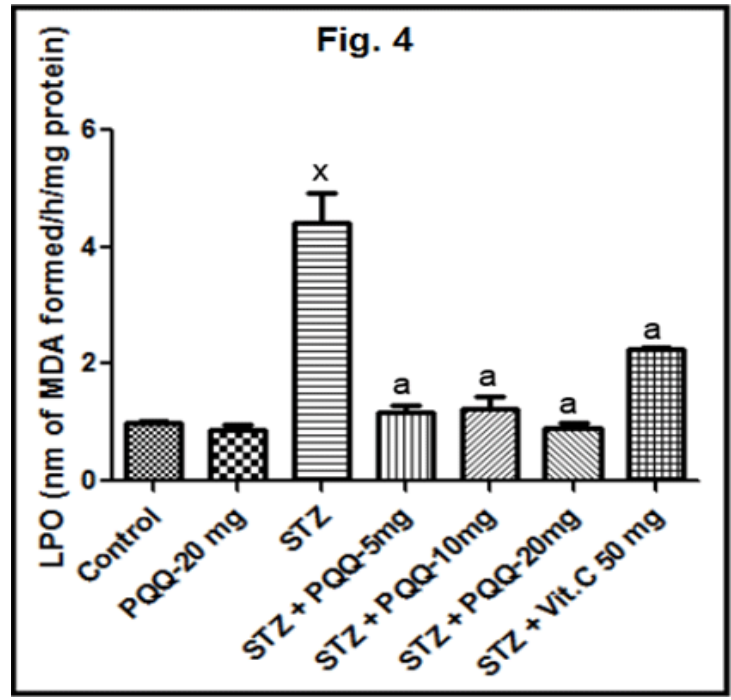

Figure 4: Effects of PQQ (5, 10 and $20 \mathrm{mg} / \mathrm{kg} /$ d, i.p.) for 15 days, in LPO (nm of MDA formed $/ \mathrm{h} / \mathrm{mg}$ protein) level in the testis. Data are mean \pm S.E.M. $(\mathrm{n}=7) . \quad \times, P<0.001$ as compared to the respective control values. a, $P<0.001$ as compared to the respective STZ treated values. ${ }^{\text {STZ, Strep- }}$ tozotocin, ${ }^{\mathrm{LPO}}$ Lipid Peroxidation, ${ }^{\mathrm{PQQ}}$ Pyrroloquinoline quinone and ${ }^{\text {Vit.C, }}$ Vitamin C

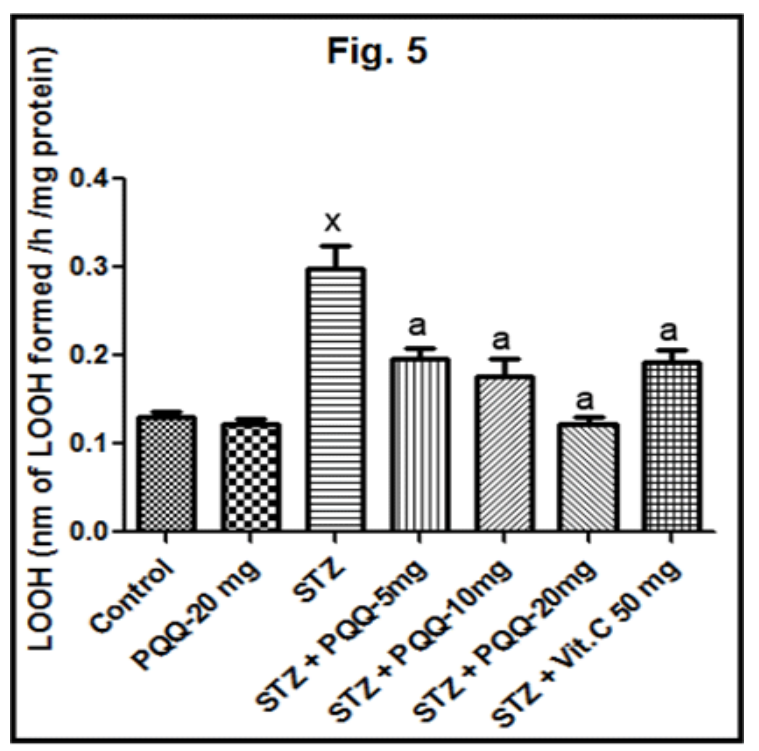

Figure 5: Effects of $\mathrm{PQQ}(5,10$ and $20 \mathrm{mg} / \mathrm{kg} / \mathrm{d}$, i.p.) for 15 days, in $\mathrm{LOOH}$ (nm of LOOH formed $/ \mathrm{h} / \mathrm{mg}$ protein) level in the testis. Data are mean \pm S.E.M. $(\mathrm{n}=7) . \quad{ }^{\mathrm{x}}, P<0.001$ as compared to the respective control values. ${ }^{\text {a, }} P<0.001$ and ${ }^{\mathrm{b}}, P<0.01$ as compared to the respective STZ


quinoline quinone and ${ }^{\text {Vit.C, }}$ Vitamin $\mathrm{C}$

observed after administration of Vit.C $50 \mathrm{mg} / \mathrm{kg}$ in diabetic animals (Figure 6). STZ administration also decreased the CAT activity significantly $(P<0.001)$, While PQQ at $20 \mathrm{mg} / \mathrm{kg}$ did not alter its activity singificantly in normoglycemic animals, PQQ (5, 10 and $20 \mathrm{mg} / \mathrm{kg}$ ) in STZ-treated mice, significantly increased its activity only at $20 \mathrm{mg} / \mathrm{kg}$ of PQQ $(P<0.001$, as compared to 
that of control ones) by 59\%. Administration of Vit.C in diabetic animals also increased SOD level significantly $(P<0.05)$ with a percentage of $29 \%$ (Figure 7). Changes in tissue GPx activity are illustrated in Fig. 8, GPx was significantly decreased in the STZ-induced diabetic mice $(P<0.01)$. While, following the administration of $20 \mathrm{mg} / \mathrm{kg}$ of PQQ to normoglycemic mice, no significant alteration in GPx activity was observed, when PQQ (5, 10 and $20 \mathrm{mg} / \mathrm{kg}$ ) was administered to STZ-treated mice, there was a significant increase in its activity at the dose of 10 and $20 \mathrm{mg} / \mathrm{kg}(P<0.01$ and $P<0.001$ respectively), of course the higher dose could increase to a greater extent with an increase of $78 \%$, while after administration of Vit.C to STZ-treated animals, significant increase in GPx level was observed $(P<0.01)$ with a percentage of $64 \%$ (Figure 8). GSH level was also significantly decreased by STZ $(P<0.01)$. While administration of $20 \mathrm{mg} / \mathrm{kg}$ PQQ to normoglycemic mice, did not significantly alter its level, when PQQ (5, 10 and $20 \mathrm{mg} / \mathrm{kg}$ ) was administered to STZ-treated animals, a significant decrease in its levels was observed in all the tested doses as compared to that of STZ-induced diabetic mice $(P<0.05, P<0.01$ and $P<0.01$ respectively). However, out of the three doses of PQQ, $20 \mathrm{mg} / \mathrm{kg}$ was found to be most effective with $62 \%$ increase. After administration of Vit.C to STZ-treated animals, significant increase with a percentage of $14 \%$ in GSH level was observed $(P<0.05)$, as compared to the respective value of STZ-induced diabetic animals (Figure 9).

With respect to alteration in different lipid levels of testis, a

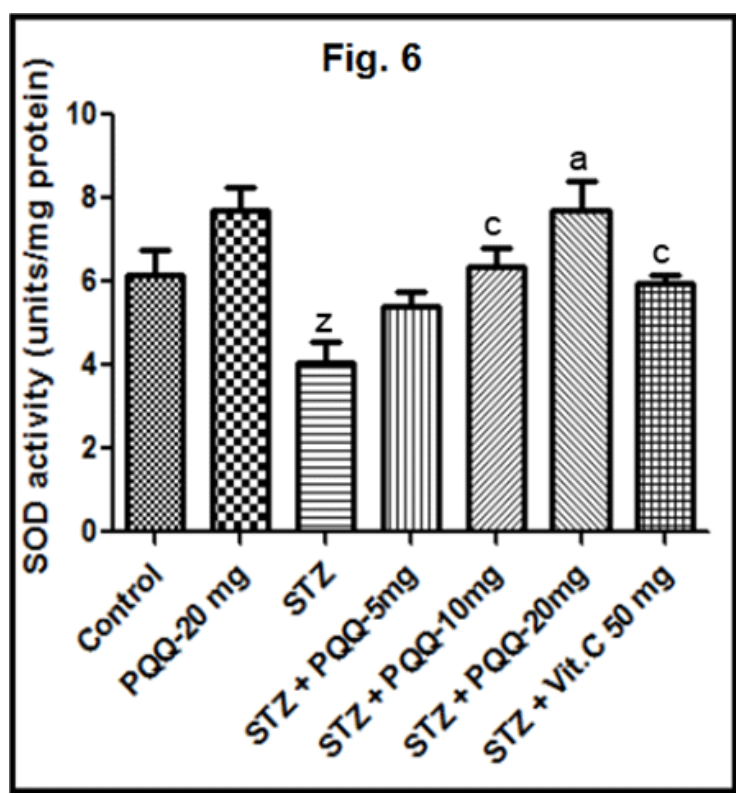

Figure 6: Effects of PQQ (5, 10 and $20 \mathrm{mg} / \mathrm{kg} / \mathrm{d}$, i.p.) for 15 days, in SOD activity (units $/ \mathrm{mg}$ protein) in the testis. Data are mean \pm S.E.M. $(\mathrm{n}=7) .{ }^{\mathrm{z}}$ $P<0.05$ as compared to the respective control values. ${ }^{\text {b. }} P<0.01$ and $P<0.05$ as compared to the STZ treated values. ${ }^{\mathrm{STZ}}$, Streptozotocin, ${ }^{\text {SOD }}$ Superoxide dismutase, ${ }^{\mathrm{QQ}}$ Pyrroloquinoline quinone and ${ }^{\text {Vit.C, }}$ Vitamin C

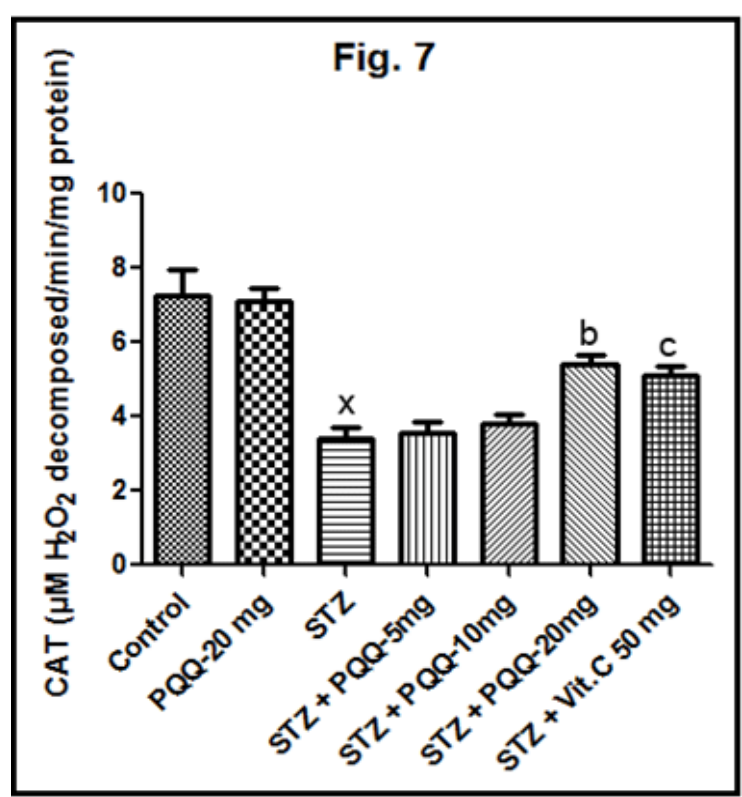

Figure 7: Effects of $P Q Q ~(5,10$ and $20 \mathrm{mg} / \mathrm{kg} /$ d, i.p.) for 15 days, in CAT activity ( $\mu \mathrm{M} \mathrm{H}_{2} \mathrm{O}_{2}$ decomposed $/ \mathrm{min} / \mathrm{mg}$ protein) in the testis. Data are mean \pm S.E.M. $(\mathrm{n}=7) .{ }^{x}, P<0.001$ as compared to the respective control values. ${ }^{\text {a }}, P<0.001$ as compared to the STZ treated values. ${ }^{\text {TTZ }}$, Streptozotocin, ${ }^{\text {CAT }}$, Catalase, ${ }^{\text {PQQ }}$, Pyrroloquinoline quinone and ${ }^{\text {Vit.C, }}$ Vitamin C

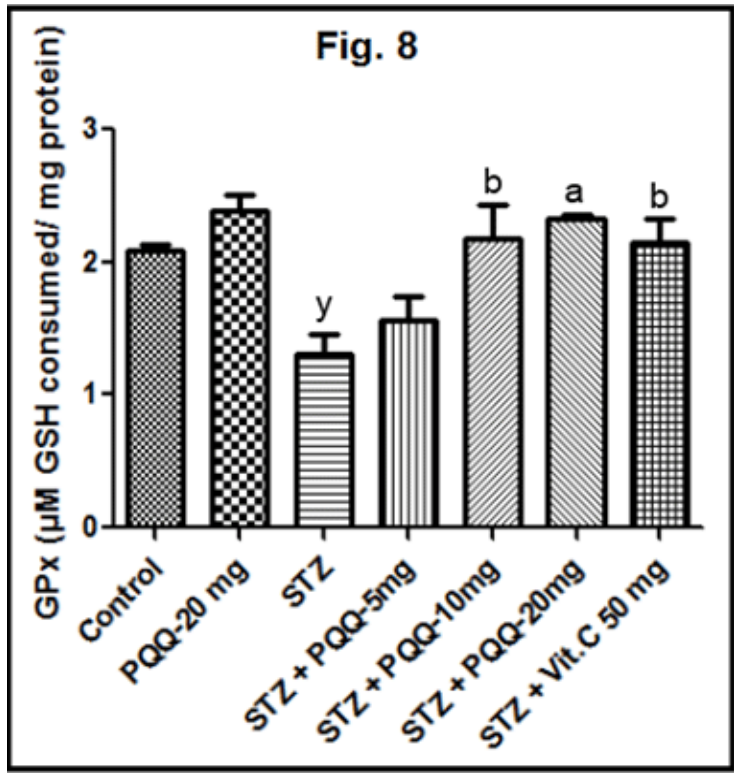

Figure 8: Effects of PQQ (5, 10 and $20 \mathrm{mg} / \mathrm{kg} /$ d, i.p.) for 15 days, in GPx activity ( $\mu \mathrm{M}$ GSH consumed /mg protein) in the testis. Data are mean \pm S.E.M. (n=7). ${ }^{x}, P<0.001$ as compared to the respective control values. a, $P<0.001$ and c, $P<0.05$ as compared to the STZ treated values. ${ }^{\text {STZ, }}$ Streptozotocin, ${ }^{\mathrm{GPX},}$ Glutathine peroxidase, ${ }^{\mathrm{PQQ}}$ Pyrroloquinoline quinone and Vit.C, Vitamin C 


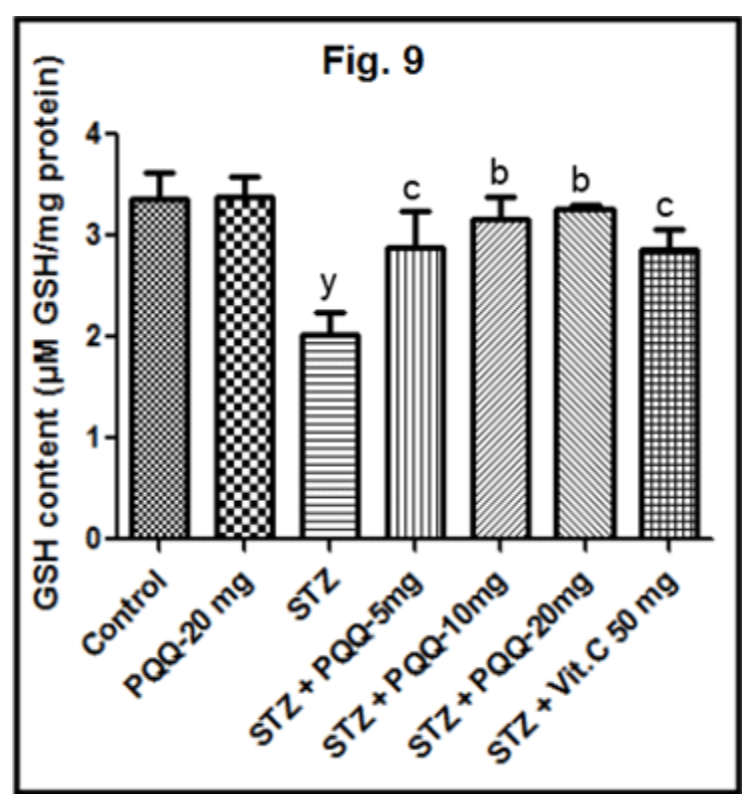

Figure 9: Effects of $P Q Q ~(5,10$ and $20 \mathrm{mg} / \mathrm{kg} / \mathrm{d}$, i.p.) for 15 days, in $\mathrm{GSH}$ content ( $\mu \mathrm{M} \mathrm{GSH} / \mathrm{mg}$ protein) in the testis. Data are mean \pm S.E.M. $(\mathrm{n}=7) .{ }^{\mathrm{z},} P<0.05$ as compared to the respective control values. ${ }^{\mathrm{b},} P<0.01$ and ${ }^{\mathrm{c},} P<0.05$ as compared to the STZ treated values. ${ }^{\mathrm{STZ}}$ Streptozotocin, GSH, Reduced glutathione, ${ }^{\text {PQQ }}$ Pyrroloquinoline quinone and Vit.C, Vitamin C

significant increase in the level of total cholesterol, triglyceride, LDL and VLDL was found in STZ treated animals $(P<0.001$ for all); the administration of $\mathrm{PQQ}$ at a dose of $20 \mathrm{mg} / \mathrm{kg}$ in STZinduced diabetic animals, markedly reduced all these indices with a percentage decrease of $30 \%, 39 \%, 30 \%$ and $39 \%$ in total cholesterol, triglyceride, LDL and VLDL respectively; as compared to that of STZ-induced diabetic mice (Figure 3). By the administration of STZ, level of serum HDL decreased significantly $(P<0.001)$. However, simultaneous administration of PQQ in STZ - induced mice; $20 \mathrm{mg} / \mathrm{kg}$ of PQQ could significantly increase the HDL level with a $21 \%$ increase $(P<0.05)$. Following the test drug administration at $20 \mathrm{mg} / \mathrm{kg}$ to normoglycemic mice, there was no significant alteration in all these indices. Administration of Vit.C to STZ - treated animals reduced significantly the levels of total cholesterol, triglyceride, LDL, VLDL in STZ-induced diabetic animals with percentage decrease of $17 \%, 20 \%, 18 \%$ and $23 \%$. While, administration of Vit.C $50 \mathrm{mg} / \mathrm{kg}$ did not alter HDL level singificantly in STZ-induced diabetic animals (Figure 10). A comparison of the effects of PQQ and Vit.C; PQQ $(20 \mathrm{mg} /$ $\mathrm{kg}$ ) showed more effectiveness than that of Vit.C (50 mg/kg) in cholesterol, triglyceride, LDL and VLDL with percentage decrease of $30 \%, 39 \%, 30 \%$ and $40 \%$ respectively for PQQ and $17 \%, 20 \%$, $18 \%$ and $23 \%$ respectively for Vit.C (Figure 10), as compared with STZ-induced diabetic animals.

With respect to histopathological observations of testis of control animals showed normal testicular architecture with normal lumen of seminiferous tubules (LST), normal thickness of the basement membrane (Bm), spermatids (S), spermatogonia

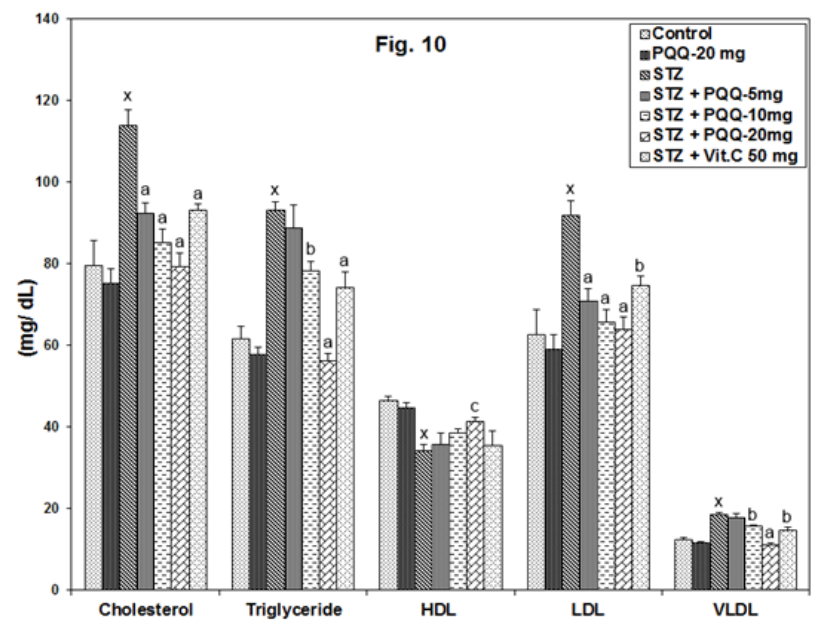

Figure 10: Effects of $P Q Q ~(5,10$ and $20 \mathrm{mg} / \mathrm{kg} / \mathrm{d}$, i.p.) sfor 15 days, in serum cholesterol, triglyceride, HDL, LDL and VLDL (mg/dl). Data are mean \pm S.E.M. $(\mathrm{n}=7) .{ }^{x}, P<0.001$ as compared to the respective control values. ${ }^{\text {a, }} P<0.001,{ }^{\text {b, }} P<0.01$ and ${ }^{c}, P<0.05$ as compared to the respective STZ treated values. ${ }^{\mathrm{HDL},}$ High density lipoprotein, ${ }^{\mathrm{LDL},}$ low density lipoprotein, ${ }^{\mathrm{VLDL}}$, Very low density lipoprotein, ${ }^{\mathrm{STZ}}$, Streptozotocin, ${ }^{\mathrm{PQQ}}$ Pyrrolo-



(Sg), Laydig cells (L) and interstitial space (I); in STZ treated group, it showed marked alterations in these normal cellular architecture as evidenced by extensive atrophy and loss in spherical shape, with narrow and elongated seminiferous tubules and LST, loss of centrally located spermatogonial cells, spermatocytes and spermatids (S) and disappearance of the connections between cells. Also increased thickness of basement membrane was observed and widening of the interstitial spaces between seminiferous tubules was quite clear. Atrophy in Leydig cells was observed in the diabetic mice. However, administration of PQQ to STZ treated animals ameliorated these deleterious effects in a dose dependent manner. Similar ameliorative effects were observed on administration of Vit.C $(50 \mathrm{mg} / \mathrm{kg})$ in STZtreated animal. No significant histological changes were observed by the administration of PQQ $(20 \mathrm{mg} / \mathrm{kg})$ to normoglycemic animals (Figure 11).

\section{Discussion}

From the results it is clearly evident that the test compound, PQQ has the potential to ameliorate the STZ-induced diabetes mellitus and oxidative damage in testis of mice as evidenced by a decrease in serum glucose, tissue LPO, LOOH, the levels of different serum lipids, insulin and testosterone. In fact, PQQ could nearly maintain the normal physiological values of almost all the indices in STZ-treated diabetic mice except with respect to CAT activity and HDL concentration, which were still less as compared to their respective normoglycemic control values. The antidiabetic effects of PQQ were supported by its antioxidative properties, as it not only inhibited tissue LPO, but also enhanced all the tested cellular antioxidants.

Earlier nothing was known on the role of PQQ in STZ-induced 


\section{Fig. 11}

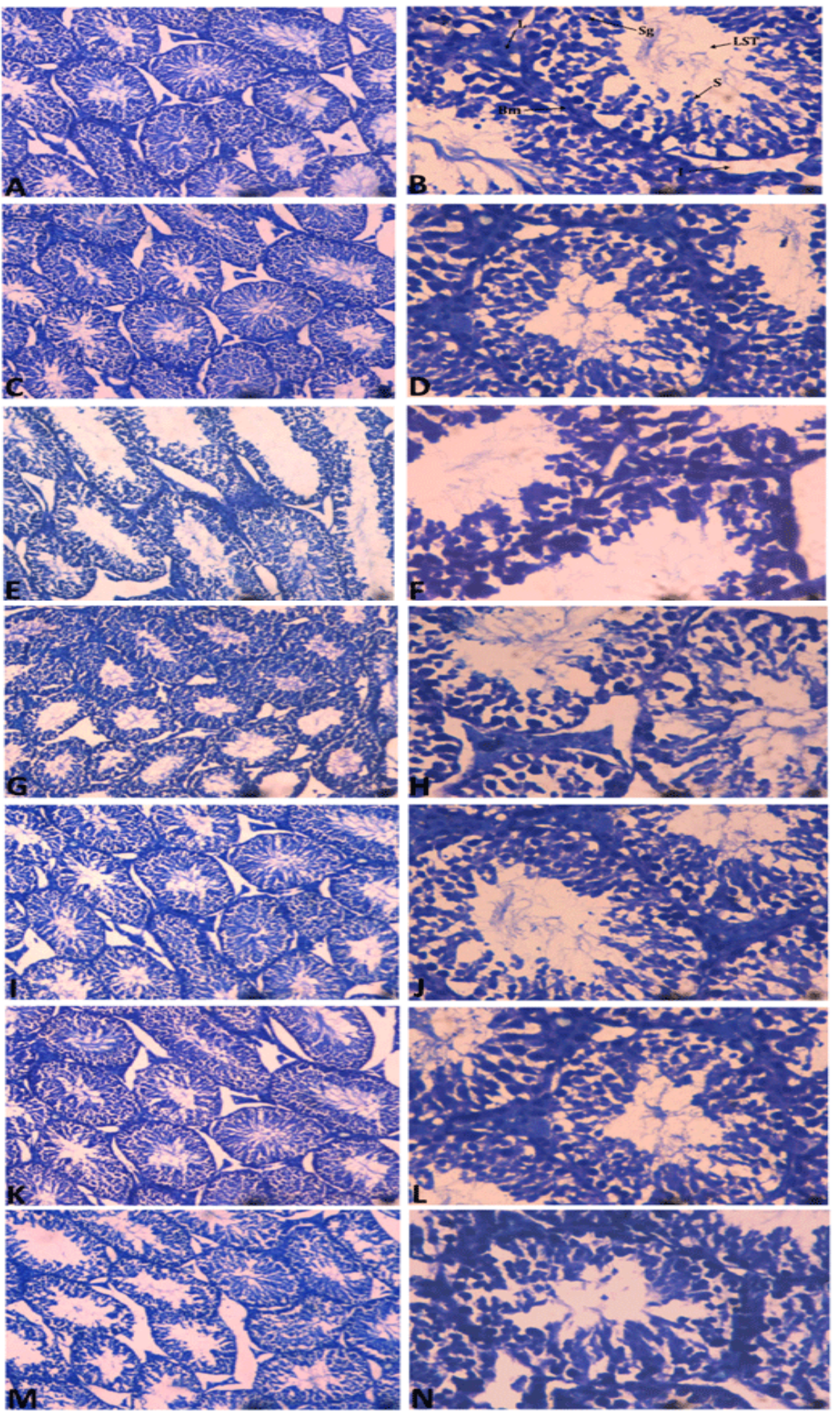

Figure 11: Photomicrographs of testis histology of representative samples from each experimental group (control mice; control treated with PQQ (20 $\mathrm{mg} / \mathrm{kg}$ ); STZ treated; and STZ + PQQ treated at 5,10 and $20 \mathrm{mg} / \mathrm{kg}$ body weight. The staining was done with toluidine blue and original magnification is $\times 10$ and $\times 40$ respectively of (A \& B). Testicular section of normal mouse testis; (C \& D) testicular section of normal animals treated only with 20 $\mathrm{mg}$ of PQQ; (E-F), testicular section of the STZ treated diabetic group; (G \& H) testicular section of the animals treated with PQQ at a dose of 5mg; (I-J) PQQ 10mg; (K \& L), PQQ $20 \mathrm{mg}$; and (M \& N) Vit. C 50mg. Control testis shows normal spermatogonia (Sg), spermatids (S), Leydig cells (L), lumen of seminiferous tubule (LST). The STZ-treated group shows, loss of normal cellular architecture, elongated and narrow seminiferous tubule and lumen of seminiferous tubules, loss of leydig cells, loss of centrally located spermatozoa, whereas PQQ treatment shows nearly normal morphology 
oxidative damage in testicular tissues. Our results for the first time revealed that PQQ treatment for 15 days could improve the adverse effects in the male primary reproductive organ of diabetic animals. STZ-induced DM was supported by significant increase in glucose and decrease in serum insulin levels, which caused marked oxidative impairments, as evidenced by the increase in MDA and LOOH levels in the testicular tissues with a parallel decrease in the activity of antioxidants. A decline in serum testosterone and HDL and an increase in serum cholesterol, triglyceride, LDL and VLDL were also observed in these animals. These observed alterations are in accordance with some earlier reports, made on the oxidative impairments in the male reproductive system of diabetic subjects $[6,7,14,46]$.

Untreated hyperglycemia very often leads to a number of complications including over-production of ROS such as superoxide anion $\left(\mathrm{O}_{2}^{-}\right)$, nitric oxide (NO-) and hydrogen peroxide $\left(\mathrm{H}_{2} \mathrm{O}_{2}\right)$; which in turn damages the beta cells through the induction of apoptosis and the suppression of insulin biosynthesis [47-54]. In-fact, STZ is known to decrease insulin biosynthesis through alkylation of DNA and overproduction of nitric oxide (NO) and other free radicals [55]. Interestingly PQQ reversed these adverse effects in the DM-induced animals by increasing the antioxidants in testis suggesting that the test drug has the antioxidant potential and to ameliorate DM-induced oxidative stress in testis.

Determination of malondialdehyde (MDA), a product of LPO is used as an important indicator of tissue peroxidation [56]. The increased level of MDA observed in STZ-induced animals similar to an earlier report [46] suggests that hyperglycemia induces peroxidative reactions in lipids [57], According to Selvakumar et al. [58] LPO and the resultant oxidative stress, play a crucial role in the development of complications in diabetes. The common free radicals that occur in this diseased state are superoxide $\left(\mathrm{O}_{2} \bullet\right)$, hydroxyl $(\mathrm{OH} \bullet)$ and peroxyl $(\mathrm{LOO} \bullet)$ radicals, that cause DNA damage, glycation and protein modification reactions in diabetes [59]. On the other hand certain enzymes play crucial role in antioxidant defense, to maintain viable reproductive ability, by providing a protective mechanism against oxidative stress. SOD and GPx are major enzymes that scavenge harmful ROS in male reproductive organs $[32,60]$. Therefore, in our study, an increase in these enzymes by PQQ, as observed earlier in other tissues [20, 21] might have protected the STZ-induced testicular damages.

Glutathione, a well-known antioxidant provides the major protection against cellular oxidative damages as it maintains $\mathrm{SH}$ level in proteins. It forms reduced GSH from oxidized glutathione that in turn reduces hydrogen peroxide, lipid peroxides, disulfides, ascorbate and free radicals. In this study STZ-treated animals exhibited reduced GSH level as was seen earlier in DM $[61,62]$. However, administration of PQQ increased the GSH level in diabetic animals, further consolidating the potential of test compound to enhance the state of this cellular antioxidant status.

Similarly, GPx is a cytosolic enzyme that complements with CAT in order to detoxify $\mathrm{H}_{2} \mathrm{O}_{2}$ and organic hydroperoxide [63]. Reduction of hydroperoxide by glutathione in the presence of GPx protects mammalian cells from oxidative damages. In the male reproductive system, GPx is abundantly found in the testis and reduction in GPx activity contributes to male infertility [64]. Interestingly, in the present investigation decrease in GPx activity in STZ-induced diabetic animals was corrected following the PQQ administration, further supporting the antioxidative and protective nature of $\mathrm{PQQ}$ in testis.

PQQ is highly electrophilic in nature and it forms stable adducts with carbonyl reagents. These characteristics provide it the ability to oxidize the redox modulatory site, thus conferring protection against ROS-mediated cell injury [65]. PQQ-induced reduction in intracellular ROS levels hypothesizes that it acts directly or indirectly as a potent free radical scavenger [66]. Probably for this reason LPO level was normalized in PQQ treated animals. Whether its site of action is intra-mitochondrial or in the cytoplasm, or both, is yet not clear [66].

The beneficial effect of PQQ was also reflected by the alterations in the level of different lipids and glucose. While, STZ administration increased the levels of serum glucose, cholesterol, triglyceride, LDL and VLDL; simultaneous PQQ administration reduced them. An increase in the serum total cholesterol is very often seen in DM in which alteration of cholesterol biosynthesis takes place, thereby increasing most of the serum lipids [67-69]. It was also reported earlier that there is a negative correlation between serum levels of triglycerides and VLDL to serum testosterone concentration [70]. Interestingly in our study, simultaneous PQQ administration decreased the cholesterol and triglyceride levels as was observed earlier by us and others [20, 29]. Since hyperlipidemia is thought to be ameliorated by the administration of antioxidants [71], PQQ might have reversed the STZ-induced adverse effects in testis by its strong antioxidant potential.

PQQ was also found to increase HDL level in STZ-induced diabetic animals. HDL, a good plasma lipoprotein, is utilized by testicular cells for androgen synthesis [72]. In fact, a good number of HDL receptors are found in the testicular tissue which may be related to its role in the testosterone synthesis [73]. Therefore, in the present study, STZ induced decrease in the HDL level appears to adversely affect the testicular function and it is increased by simultaneous administration of PQQ that maintains its normal level. Changes in the histopathological features of testis in PQQ treated animals, showing normal secretory function of the sertoli and leydig cells also support the positive effects of PQQ in spermatogenesis. Our results do corroborate with earlier reports where HDL level was directly correlated with testicular functions [69].

STZ-induced hyperglycemia leads to reduced leydig cell function, decreased testosterone level and the alterations in the seminiferous epithelium [74-76]. This is also known that increased level of free radicals and oxidative stress reduces the level of testosterone in diabetic animals $[77,78]$. As testosterone is required for germinal cell health and for their mitotic division, the enhanced testosterone level in this study in PQQ treated diabetic animals might have prevented the testicular damages as supported by its positive effects on testicular histology and 
on testosteron level in diabetic mice, suggesting its potential to correct the STZ-induced testicular dysfunction [79].

The possible mechanism of PQQ ameliorating STZ-induced testicular oxidative stress could be due to its strong antioxidant properties, as suggested in an earlier study, in which the free radical scavenging activity of $\mathrm{PQQ}$ has been clearly shown [16]. Although the exact mechanism of action of PQQ in the diabetic testis is not clear, from the present study, it appears that the beneficial effects are associated with its antioxidant properties, as we suggested earlier in hypothyroid mice [21]. Another possible mechanism for hypoglycemic action of PQQ in the present study could be through the regulation of phosphatidylinositol 3-kinase (PI3K) /Akt signaling pathway, which is known to control the glucose homeostasis [80]. This concept is further supported by a recent report in which it was stated that $P Q Q$ exhibits its protective effects via activating the PI3K / AKT pathway [81]. Although in the present investigation also the effects of $\mathrm{PQQ}$ in regulating DMinduced oxidative damages might have been mediated through activation of PI3K/ AKT pathway; exact mechanism remains to be worked out.

This may be emphasized that nothing was known till date on the role of $\mathrm{PQQ}$ in regulating STZ-induced oxidative stress in testis of diabetic ones, despite the fact that $\mathrm{PQQ}$ regulates liver, kidney and heart which are often associated with DM [32, 20]. Therefore, the present report appears to be the first one that clearly indicates the efficacy of PQQ in regulating STZ-induced oxidative damages in testis. Interestingly, the ameliorative effects were better expressed by PQQ as compared to that of Vit.C.

\section{Conclusion}

In conclusion, to the best of our knowledge, this work is the first report documenting the potential of PQQ to ameliorate diabetes mediated testicular damages through its effective regulation of glucose and lipid metabolism. Our findings provide a substantial basis for future investigations for assessing new PQQ based therapies for the treatment of diabetes associated reproductive problems. Interestingly, the ameliorative effects were better expressed by $\mathrm{PQQ}$ as compared to that of Vit.C. However, the detailed molecular mechanism underlying the effects requires further intensive investigations.

\section{Acknowledgement}

Financial support from the Council of Scientific and Industrial Research (CSIR), New Delhi, India. Ref. No. 09/301/(0121)/2011EMR I for a Senior Research fellowship to Narendra Kumar is gratefully acknowledged.

\section{References}

1. Gavin III JR, Alberti KGMM, Davidson MB, De Fronzo RA, Drash A, Gabbe SG. Report of the expert committee on the diagnosis and classification of diabetes mellitus. Diab Care. 1997;20(7):1183-1197.

2. Wiernsperger NF. Oxidative stress as therapeutic target in diabetes: revisiting the controversy. Diab Metab. 2003;29(6):579-585.

3. Annuziata L, Domenico F, Pietro T. Glyco-oxidation in diabetes and related disease. Clin Chim Acta. 2005;357(2):236-250.

4. Jiang GY. Practical diabetes Beijing: People's Health Publishing House. Beijing. 1996;295.

5. Gomez O, Ballester B, Romero A, Arnal E, Almansa I, Miranda M, et al. Expression and regulation of insulin and the glucose transporter GLUT8 in the testes of diabetic rats. Horm Metab Res. 2009;41(5):343349. 6. Agbaje IM, Rogers DA, McVicar CM, McClure N, Atkinson AB, Mallidis C, et al. Insulin dependent diabetes mellitus: implication for male reproductive function. Hum Reprod. 2007;22(7):1871-1877.

7. Amaral S, Moreno AM, Santos MS, Seica R, Ramalho-Santos J. Effects of hyperglycemia on sperm and testicular cells of Goto-Kakizaki and streptozotocin-treated rat models for diabetes. Theriogenology. 2006;66(9):2056-2067.

8. Mallidis C, Agbaje I, O'Neill J, McClure N. The influence of type 1 diabetes mellitus on spermatogenic gene expression. Fertil Steril. 2009;92(6):2085-2087

9. Karimi J, Goodarzi MT, Tavilani H, Khodadadi I, Amiri I. Relationship between advanced glycation end products and increased lipid peroxidation in semen of diabetic men. Diabetes Res Clin Pract. 2011;91(1):61-66.

10.Sivan E, Reece EA, Wu YK, Homko CJ, Polansky M. Dietary vitamin E prophylaxis and diabetic embryopathy: Morphologic and biochemical analysis. Am J Obstet Gynecol. 1996;175 (4 Pt 1):793-799.

11. Rahimi R, Nikfar S, Larijani B, Abdollahi M. A review on the role of antioxidants in the management of diabetes and its complications. Biomed Pharmacother. 2005;59(7):365-373.

12. Aybek H, Aybek Z, Rota S, Sen N, Akbulut M. The effects of diabetes mellitus, age, and vitamin $\mathrm{E}$ on testicular oxidative stress. Fertil Steril. 2008;90(3):755-760.

13. Mohasseb M, Ebied S, Yehia MAH, Hussein N. Testicular oxidative damage and role of combined antioxidant supplementation in experimental diabetic rats. J Physiol Biochem. 2011;67(2):185-194.

14. Gren A. Effects of vitamin E, C and D supplementation on inflammation and oxidative stress in streptozotocin-induced diabetic mice. Int J Vitam Nutr Res. 2013;83(3):168-175.

15. Guo W, Kong E, Meydani M. Dietary polyphenols, inflammation, and cancer. Nutr cancer. 2009;61(6):807-810.

16. Misra HS, Rajpurohit YS, Khairnar NP. Pyrroloquinoline-quinone and its versatile roles in biological processes. J Biosci. 2012;37(2):313325 .

17. Kasahara T, Kato T. Nutritional biochemistry: a new redox-cofactor vitamin for mammals. Nature. 2003;422(6934):832.

18. Misra HS, Khairnar NP, Barik A, Indira Priyadarsini K, Mohan H, Apte SK. Pyrroloquinoline-quinone: a reactive oxygen species scavenger in bacteria. FEBS Lett. 2004;578(1-2):26-30.

19. Rajpurohit YS, Gopalakrishnan R, Misra HS. Involvement of a protein kinase activity inducer in DNA double strand break repair and radioresistance of Deinococcus radiodurans. J Bacteriol. 2008;190(11):3948-3954.

20. Kumar N, Kar A. Regulation of oxidative stress and lipid peroxidation in PTU induced mice, treated with Pyrroloquinoline quinone (PQQ). IOSR-JBPS. 2013;8:23-31.

21. Kumar N, Kar A. Pyrroloquinoline quinine has potential to ameliorate PTU induced lipid peroxidation and oxidative damages in mice. Int J 
Pharm Pharm Sci. 2014;6(2):880-885.

22. Hamagishi Y, Murata S, Kamei H, Oki T, Adachi O, Ameyama M. New biological properties of PQQ and its related compounds: inhibition of chemiluminescence, lipid peroxidation and rat paw edema. J Pharmacol Exp Ther. 1990;255(3):980-985.

23. Smidt CR, Steinberg FM, Rucker RB. Physiologic importance of pyrroloquinoline quinine. Proc Soc Exp Biol Med. 1991;197(1):19-26.

24.Wu QS, Wang JH, Zhou YH, Qin F, Shen L, Wu SL. Effect of pyrroloquinoline quinoneon free radical in rats with radiation induced skin injury. J Jiangsu Univ. 2008;18:403-405.

25. Qiu XQ, Liu CL, Xu L, Zhao JY, Wu SL. Effect of pyrroloquinoline quinone on antioxidative competence of AGS cell radiated by $\gamma$-ray. J Jiangsu Univ (Med. Ed.). 2009;19:293-295.

26. Wojciechowski P, Juric D, Louis XL, Thandapilly SJ, Yu L, Taylor C, et al. Resveratrol arrests and regresses the development of pressure overload but not volume overload-induced cardiac hypertrophy in rats. J Nutr. $2010 ; 140: 962-968$.

27. Stites TE, Mitchell AE, Rucker RB. Physiological importance of quinoenzymes and the O-quinone family of cofactors. J Nutr. 2000;130(4):719-727.

28. Stites T, Storms D, Bauerly K, Mah J, Harris C, Fascetti A, et al. Pyrroloquinoline quinone modulates mitochondrial quantity and function in mice. J Nutr. 2006;136(2):390-396.

29. Bauerly K, Harris C, Chowanadisai W, Graham J, Havel PJ, Tchaparian E, et al. Altering Pyrroloquinoline Quinone Nutritional Status Modulates Mitochondrial, Lipid, and Energy Metabolism in Rats. PLos One. 2011;6(7):1-13.

30.Zhang Q, Shen M, Ding M, Shen D, Ding F. The neuroprotective action of pyrroloquinoline quinone against glutamate-induced apoptosis in hippocampal neurons is mediated through the activation of PI3K/Akt pathway. Toxicol Appl Pharmacol. 2011;252(1):62-72.

31. Li R, Liang T, Xu L, Li Y, Zhang S, Duan X. Protective effect of cinnamon polyphenols against STZ-diabetic mice fed high-sugar, high-fat diet and its underlying mechanism. Food Chem Toxicol. 2013;51:419-425.

32.Zhu BQ, Simonis U, Cecchini G, Zhou HZ, Li L, Teerlink JR, et al Comparison of pyrroloquinoline quinone and/or metoprolol on myocardial infarct size and mitochondrial damage in a rat model of ischemia/reperfusion injury. J Cardiovasc Pharmacol Ther. 2006;11(2):119-128.

33. Takada M, Sumi M, Maeda A, Watanabe F, Kamiya T, Ishii T, et al Pyrroloquinoline quinone, a novel protein tyrosine phosphatase $1 \mathrm{~B}$ inhibitor, activates insulin signaling in $\mathrm{C} 2 \mathrm{C} 12$ myotubes and improves impaired glucose tolerance in diabetic KK-Ay mice. Biochem Biophys Res Commun. 2012;428(2):315-320.

34. Deepa PR, Varlakshmi P. Protective effects of certoparin sodium, a low molecular weight heparin derivative, in experimental atherosclerosis. Clin Chim Acta. 2004;339(1-2):105-115.

35. Ohkawa H, Ohishi N, Yagi K. Assay for lipid peroxides in animal tissues by thiobarbiturie acid reaction. Anal Biochem 1979;95:351-358.

36. Griffiths G, Leverentz M, Silkowski H, Gill N, Sanchez-Serrano JJ. Lipid hydroperoxide levels in plant tissues. J Exp Bot. 2000;51:1363-1370.

37. Marklund S, Marklund G. Involvement of superoxide anion radical in the autoxidation of pyrogallol: A convenient assay for superoxide dismutase. Eur J Biochem. 1974;47(3):469-474.

38. Aebi HE. Catalase. In: Bergmeyer HU (ed). Methods in Enzymatic Analysis. Academic Press, New York. 1983;3:276-286.
39. Ellman GL. Tissue sulfhydryl groups. Arch Biochem Biophys. 1959;82(1):70-77.

40. Mohandas J, Marshall JJ, Duggin GG, Horvath JS, Tiller DJ. Differential distribution of glutathione andglutathione related enzymes in rabbit kidney: possible interactions in analgesic neuropathy. Biochem Pharmocol. 1984;33(11):1801-1807.

41. Lowry OH, Rosebrough NJ, Farr AL, Randal RJ. Protein measurement with the Folin phenol reagent. J Biol Chem . 1951;193(1):265-275.

42. Trinder P. Determination of blood glucose using an oxidaseperoxidase system with a non-carcinogenic chromogen. J Clin Pathol. 1969;22:158-161.

43. Allain CC, Poon LS, Chan CS, Richmond W, Fu PC. Enzymatic determination of total serum cholesterol. Clin Chem. 1974;20(4):470475 .

44. Burstein M, Scholnick HR, Morfin R. Rapid method for the isolation of lipoproteins from human serum by precipitation with polyanions. J Lipid Res. 1970;11(6):583-595.

45. Friedwald WT, Levy RI, Fredrickson DC. Estimation of the concentration of low density lipoprotein cholesterol in plasma without use of the preparative ultracentrifuge. Clin Chem. 1972;18(6):499-502.

46. Shrilatha B, Muralidhara DR. Occurrence of oxidative impairments, response of antioxidant defences and associated biochemical perturbations in male reproductive milieu in the streptozotocindiabetic rat. Int J Androl. 2007;30(6):508-518.

47. Saxena AK, Srivastava P, Kale RK, Baquer NZ. Impaired antioxidant status in diabetic rat liver: effect of vanadate. Biochem Pharmacol. 1993;45(3):539-542.

48. Kroncke KD, Fehsel K, Sommer A, Rodriguez ML, Kolbbachofen V. Nitric oxide generation during cellular metabolization of diabetogenic $\mathrm{N}$-methyl-N-nitrosourea streptozotocin contributes to islet cell DNA damage. Biol Chem Hoppe Seyler. 1995;376(3):179-185.

49. Young IS, Tate S, Lightbody JH, McMaster D, Trimble ER. The effects of desferrioxamine and ascorbate on oxidative stress in the streptozotocin diabetic rat. Free Radic Biol Med. 1995;18(5):833-840.

50.Sepici A, Gurbuz I, Cevik C, Yesilada E. Hypoglycaemic effects of myrtle oil in normal and alloxan-diabetic rabbits. J Ethnopharmacol. 2004;93(2-3):311-318.

51. Murugan P, Pari L. Antioxidant effect of tetrahydrocurcumin in STZnicotinamide induced diabetic rats. Life Sci. 2006;79(18):1720-1728.

52.Vijayakumar M, Govindarajan R, Rao GMM, Rao Ch V, Shirwaikar A, MehrotraS, etal. Action of Hygrophila auriculata againststreptozotocininduced oxidative stress. J Ethnopharmacol. 2006;104(3):356-361.

53. Kataya HA, Hamza AA. Red Cabbage (Brassica oleracea) Ameliorates Diabetic Nephropathy in Rats. Evidence-based complement alternat med. 2008;5(3):281-287.

54. Jangir RN, Jain GC. Diabetes mellitus induced impairment of male reproductive functions: a review. Curr Diabetes Rev. 2014;10(3):147157.

55. Kwon NS, Lee SH, Choi CS, Kho T, Lee HS. Nitric oxide generation from streptozotocin. FASEB J. 1994;8(8):529-533.

56. Qujeq D, Aliakbarpour HR, Kalavi K. Relationship between malondialdehyde level and glutathione peroxidase activity in diabetic rats. Clin Chim Acta. 2004;340(1-2):79-83.

57. Hunkar T, Aktan F, Ceylan A, Karasu C. Antioxidants in Diabetesinduced Complications (ADIC) Study Group, Effects of cod liver oil on tissue antioxidant pathways in normal and streptozotocin-diabetic 
rats. Cell Biochem Funct. 2002;20: 297-302.

58. Selvakumar E, Prahalathan C, Sudharsan PT, Varalakshmi P. Chemoprotective effects of lipoic acid against cyclophosphamideinduced changes in the rat sperm. Toxicology. 2006;217(1):71-78

59. Hunt JV, Smith CC, Wolff SP. Auto-oxidative glycosylation and possible involvement of peroxides and free radicals in LDL modification by glucose. Diabetes. 1990;39(11):1420-1424.

60. Fujii J, Iuchi Y, Matsuki S, Ishii T. Cooperative function of antioxidant and redox systems against oxidative stress in male reproductive tissues. Asian J Androl. 2003;5(3):231-242

61. McLennan SV, Heffernan S, Wright L, Rae C, Fisher E, Yue DK, et al Changes in hepatic glutathione metabolism in diabetes. Diabetes. 1991;40(3):344-348.

62. Strain JJ. Disturbances of micronutrient and antioxidant status in diabetes. Proc Nutr Soc. 1991;50(3):591-604.

63. Sen CK, Atalay M, Hanninen O. Exercise-induced oxidative stress glutathione supplementation and deficiency. J Appl Physiol 1994;77(5):2177-2187.

64. Vernet P, Aitken RJ, Drevet JR. Antioxidant strategies in the epididymis. Mol Cell Endocrinol. 2004;216(1-2):31-39.

65. Aizenman E, Hartnett KA, Zhong C, Gallop PM, Rosenberg PA Interaction of the putative essential nutrient pyrroloquinoline quinone with the N-methyl-D-aspartate receptor redox modulatory site. J Neurosci. 1992;12(6):2362-2369.

66. Tao R, Karliner JS, Simonis U, Zheng J, Zhang J, Honbo N, et al Pyrroloquinoline quinone preserves mitochondrial function and prevents oxidative injury in adult rat cardiac myocytes. Biochem Biophys Res Commun. 2007;363(2):257-262.

67. Abbate SL, Brunzell JD. Pathophysiology of hyperlipidemia in diabetes mellitus. J Cardiovasc Pharmacol. 1990;16 Suppl 9:S1-7.

68. Rajalingam R, Srinivasan N, Govindarajulu P. Effects of alloxan induced diabetes on lipid profiles in renal cortex and medulla of mature albino rats. Ind J Exp Biol. 1993;31(6):577-559.

69. Lodovici M, Bigagli E, Bardini G, Rotella CM. Lipoperoxidation and antioxidant capacity in patients with poorly controlled type 2 diabetes.
Toxicol Ind Health. 2009;25(4-5):337-341.

70. Louei Monfared A. Correlation of Serum Lipid Profile with Histological and Seminal Parameters of Testis in the Goat. Int J Fertil Steril. 2013;7(2):122-129.

71. Ahmed RG. The physiological and biochemical effects of diabetes on the balance between oxidative stress and antioxidant defense system. Med J Islamic World Acad Sci. 2005;15(1):31-42.

72. Forte TM, Bell-Qumt JJ, Cheng F. Lipoproteins of fetal and new born calves and adult steers: a study of developmental changes. Lipids. 1981;16(4):240-245.

73. Padron RS, Mas J, Zamora R, Riverol F, Licea M, Mallea L, et al. Lipids and testicular function. Int Urol Nephrol. 1989;21(5):515-519.

74. Ergun A, Kose SK, Aydos K, Ata A, Avci A. Correlation of seminal parameters with serum lipid profile and sex hormones. Arch Androl. 2007;53(1):21-23.

75. Shahreari Sh, Khaki A, Ahmadi-Ashtiani HR, Hajiaghaei R, Rezazadeh Sh. Effects of Danae racemosa on Testosterone Hormone in Experimental Diabetic Rats. J Med Plants. 2010;3(35):114-119.

76. Khaneshi F, Nasrolahi O, Azizi S, Nejati V. Sesame effects on testicular damage in streptozotocin-induced diabetes rats. Avicenna J Phytomed. 2013;3(4):347-355.

77. Aitkem RJ, Clarkson JS, Hargreave TB, Irvine DS, Wu FC. Analysis of the relationship between defective sperm function and generation of reactive oxygen species in case of oligospermia. J Androl 1989;10(3):214-220

78. Sarkar R, Mohanmad KP, Chowdhury M. Effects of an organophosphate pesticide, quinalphos, on the hypothalamo-pituitary-gonadal axis in adult male rats. J Reprod Fertil. 2000;118(1):29-38.

79. Bairy K, Ganesh K, Rao Y. Effect of acyclovir on the sperm parameters of albino mice. Indian j physiol Pharmacol. 2009;53(4):327-333.

80. Ozmen A, Unek G, Kipmen-Korgun D, Korgun ET. The PI3K/Akt and MAPK-ERK1/2 pathways are altered in STZ induced diabetic rat placentas. Histol Histopathol. 2014;29(6):743-756.

81. Xu F, Yu H, Liu J, Cheng L. Pyrroloquinoline quinone inhibits oxygen/ glucose deprivation-induced apoptosis by activating the PI3K/AKT 